\title{
First-Year Accounting Student Teachers' Constructivist Learning Experiences, The Lecturer's Role and Implications for Curriculum Implementation
}

\author{
Medson Mapuya \\ Sol Plaatje University, Kimberley, South Africa \\ https://orcid.org/0000-0002-7331-5113
}

\begin{abstract}
The purpose of this study was to explore the constructivist learning experiences of first-year accounting student teachers and the implications these learning experiences have for curriculum implementation. The study employed a phenomenological research design and followed a qualitative research approach in which data were collected using focus group interviews. Content analysis and qualitative coding were used to analyse the qualitative data generated by the focus group interviews. Premised on the findings, the study recommends that as key stakeholders involved in curriculum implementation, lecturers should engage empathically with students on issues regarding pedagogy and subject didactics. Of central importance to the recommendations made in this study is that key questions regarding teaching and learning activities should be informed by the dynamic learning needs of students. It therefore follows that lecturers ought to adopt a more studentparticipative, collaborative and consultative approach towards curriculum implementation and obtain regular feedback from students about their learning experiences.
\end{abstract}

Keywords: constructivist learning experiences; curriculum implementation; student teachers

\section{Introduction}

The transition from high school to university education marks a radical shift from a highly supportive and structured learning environment to one that is more complex and sophisticated and that emphasises autonomous learning (Mapuya, 2018; Millet, 2015; Pieterse, 2015; Hodgson, Lam and Chow, 2010). Consequently, this transition is traditionally associated with a plethora of challenges for firstyear students. These include curriculum implementation approaches which are not compatible with their learning styles; lack of lecturer and peer support; a hostile, uncollaborative, individualistic, demotivating and demoralising learning 
environment; abstract meaningless learning experiences; self-centred competition; emotional insecurity and new social and academic systems (Wangeri, Kimani and Motweleli, 2012; Millet, 2015; Pieterse, 2015). In the same vein, Mbude (2018) cites the Cambridge Assessment International Education Report indicating that $85 \%$ of learners in South Africa aspire to enrol at institutions of higher learning. However, according to Mbude (2018), very few of those students will graduate within the course completion period.

Further to the above, Du Toit (2018), Seroto (2015) and Ko and Chung (2014) jointly caution that the social dynamics in the higher education learning environment have a material effect on the learning experiences of students. Against this backdrop, it is necessary to establish and maintain an academically supportive, friendly and participative learning environment which promotes the academic success and course completion rates of students. This call is made in light of research evidence presented by Fardon (2013), Fayombo (2015), Bautitsa (2014), Bosman (2015) and Pollard (2014) that academic performance is correlated with the students' learning experiences and the approaches that are used to implement the curriculum (Killen, 2016; Radovan and Makovec, 2015).

Given the foregoing, Nel, Nel and Hugo (2012) and Mapuya (2018) make a plausible argument that the dynamism and complexity of the learning environment in which students access the curriculum should always be the premise for educational research on the learning experiences of students. From the above submissions, it is therefore necessary to understand how students interpret and perceive their learning experiences. Such understanding can potentially galvanize lecturers to create and foster positive learning experiences for students. These learning experiences should be orchestrated around the precepts and pedagogical assumptions of social constructivism as propounded and pioneered by Vygotsky $(1978,1986)$. Regrettably, Gilakjani, Leong and Ismail (2013) lament that a critical analysis of the nature and type of teaching to which students are exposed reveals that very little has changed from the highly lecturercentred learning environments where the lecturer merely passes information to students and gives orders.

Davids and Waghid (2020) caution that while academic performance remains at the core of success, access and retention in higher education, students experience the most severe sense of exclusion, alienation and displacement in the learning environment. The reasons advanced by Davids and Waghid (2020) for this are that the students are not able to navigate through the demands and expectations of the learning environment and that they are never heard or seen. Although the dominant discourses of teaching and learning and the students' learning experiences in higher education tend to differ significantly among institutions, socially, geographically, economically and politically they are defined by specific discourses which form part of the pedagogical ethos and teaching culture in the learning environment.

Makola (2016) and Mapuya (2018) share the interest and concern of Davids and Waghid (2020) about the poor completion rates of students in higher education. While Davids and Waghid (2020) attribute this to lack of transformation in the higher education landscape and the learning environment, Yadav (2016) and 
Mapuya (2018) share the commonly held view that this is a result of a lack of a radical paradigm shift in curriculum implementation approaches. To this effect, Akalu (2017) cautions that increased student participation is crucial towards the democratisation of access and completions rates by not only making higher education available to many students but also through ensuring that curriculum implementation is conscious of the students' learning needs (Jensen and Frederick, 2016; Van Wyk and Dos Reis, 2016; Mapuya, 2018).

In the same vein, Davids and Waghid (2020) caution that critical to the idea of student participation in higher education is the fact that the increased enrolment of students signifies the broadening and diversifying of the learning environment and educational setup in higher education. As such, student diversity points to a high probability of different perspectives and voices with regard to what constitutes meaningful, effective learning experiences and ideal curriculum implementation approaches. Thus, the pedagogical views of Vygotsky (1978, 1986) as discussed below, become critical in this regard.

In alignment with the above theoretical perspectives, this study sought to address the following questions:

- What are the constructivist learning experiences of first-year accounting student teachers?

- What is the role of the lecturer in a constructivist learning environment for accounting?

- How do the constructivist learning experiences of students implicate curriculum implementation approaches in accounting education?

\section{Conceptualisation of Social Constructivism, Pedagogy and Education}

Social constructivism has been defined in various ways by different scholars, intellectuals and researchers of diverse interests and disciplines in education, management, sociology and psychology (Vygotsky, 1978, 1986; Lombard and Themane, 2015; Van Wyk and Dos Reis, 2016; Ormrod, 2014b; Tulbure, 2012). Concurring with the above sentiments, Yadav (2016) admits that the constructivist pedagogical approach has been viewed in many different perspectives and has also been underpinned by a host of assumptions. Among others, these are radical constructivism, trivial constructivism, cultural constructivism and social constructivism.

Expressing their theoretical position on the definition of constructivism, Gilakjani et al. (2013) perceive constructivism to be a philosophical school of thought which assumes that reality is the mental construction of individuals who believe that they were involved in its discovery and investigation. Hence, this view of constructivism follows that learning is regarded as a self-regulated activity in which concrete experiences, reflection and discussion are used to resolve inner conflicts that emerged. The perspectives of Gilakjani et al. (2013) are consistent with the stance taken by Ormrod (2014b) and Peach-Squibb (2014) who asserted that the social constructivist school of thought acknowledges learning as an active and socially dependant construction of knowledge, meaning and understanding. Peach-Squibb (2014) advanced that this construction of knowledge, meaning and understanding is not limited by age or the stage of cognitive development. 
Instead, it emphasises the importance of student involvement and participation in the actual development of personally important and relevant perspectives of? the subject matter.

In addition, Gilakjani et al. (2013) and Van Wyk (2016) subscribe to the earlier views of Vygotsky $(1978,1986)$. As such, they both argue that at the centre of the arguments advanced by constructivists is the assumption that knowledge, meaning and understanding must be personally constructed by students and not supplied by the lecturer. Ormrod (2014) also supports the above assertions. Therefore, Ormrod (2014) views social constructivism as a theoretical perspective which looks at the collective efforts of individuals to construct and impose meaning on the world from their experiences. In the same vein, Yadav (2016) maintains that the major assumption of constructivism is that students can actively construct their own knowledge and understanding of the subject matter, premised on their own lived experiences. This argument is in harmony with the earlier perspectives of Nie and Lau (2010) and Peach-Squibb (2014) that constructivism emphasises the culture, social context and collaborative nature of learning.

Social constructivism assumes that while knowledge is created by an individual student, it is enhanced, precipitated and shaped by the social interactions and collaboration of students in the learning environment. In Yadav's (2016) understanding, social constructivism is an approach to pedagogy which holds that learning is a social process which involves real life experiences, real world experiences, language, collaboration, cooperation and interaction among students.

A critical prognosis of the above perspectives reveals that the interest of social constructivists is fundamentally rooted and anchored in the internal aspects of the teaching and learning process. Van Wyk and Dos Reis (2016) and Lombard and Themane (2015) all subscribe to the earlier sentiments of Vygotsky $(1978,1986)$ that social constructivism is a theoretical perspective which emphasises the shared and collective efforts of students to construct and impose meaning on the world from their experiences. To this effect, Jensen and Frederick (2016) postulate that social constructivism maintains that the social, cultural and historical contexts in which students grow up and in which they find themselves have some serious effects on and implications for their thinking, learning and effective classroom instruction.

As propounded by Vygotsky $(1978,1986)$, students create knowledge and understanding from their experiences and observations rather than by memorising and absorbing facts. In trying to expand this narrative, Lombard and Themane (2015) and Ormrod (2014b) concur that social constructivists assume that individuals put together what they learn into solid bodies of knowledge and beliefs that may either be inaccurate or correct. An equally important feature of social constructivism is that it concentrates on how students create and acquire knowledge through their personal interactions with the environment, a process which Ormrod (2014) understands as individual constructivism.

Another significant factor about social constructivism is that it maintains that through working together, two or more students can negotiate and create a better 
understanding than an individual student can obtain when working alone (Ormrod, 2014; Vygotsky, 1978). Premised on the above theoretical perspective, it therefore follows that social constructivism advocates for the socialisation of the teaching and learning process and regards peer collaboration and cooperation as important variables for successful implementation of the accounting curriculum.

\section{Social Constructivism in Accounting Education and the Role of the Lecturer in a Social Constructivist Learning Environment}

Research findings globally indicate that the pedagogical assumptions of social constructivism have been widely embraced and acknowledged (Visser and Vreken, 2013; Daniel and Bimbola, 2010; Taole, 2015; Van Wyk and Dos Reis, 2016). However, the actual implementation of these social constructivist assumptions in accounting pedagogy and the learning environment has been largely unsatisfactory and minimal. In addition, since the advent of the idea of social constructivist teaching and learning (Vygotsky, 1978, 1986; Visser and Vreken, 2013; Daniel and Bimbola, 2010; Taole, 2015; Van Wyk and Dos Reis, 2016), there has been a phenomenal global research interest in the educational gains of social constructivism.

As a pioneer and ardent advocate of social constructivism in teaching and learning, Vygotsky $(1978,1986)$ highlighted the cognitive and pedagogical effects of social constructivism and its subsequent benefits in education. As a result of these professed gains of social constructivism in the teaching and learning process, there has been satisfactory enduring interest in researching its application. As such, verdicts from the literature (Horsthemke, Siyakwazi, Walton and Wolhuter, 2013; Mapuya, 2018; Vygotsky, 1978, 1986; Lombard and Themane, 2015; Killen, 2016; Jacobs, 2016; Daniel and Bimbola, 2010; Van Wyk and Dos Reis, 2016) with respect to social constructivism demonstrate a shared emphasis on the socialisation of the teaching and learning process, with active student participation at the core.

An extensive review of relevant literature has revealed no currently existing prescriptions on the roles of the accounting lecturer in an accounting social constructivist learning environment. However, the participative, interactive and practical nature of the accounting content resonates well with the pedagogical imperatives of social constructivism. It is highly compatible with the assumptions of social constructivism as advanced by Vygotsky (1978). As such, social constructivism finds relevance and applicability in accounting education, despite the absence of application guidelines.

Yadav (2016) subscribes to the earlier views of Gilakjani et al. (2013) and Ginny (2012) that every student in the learning environment is regarded as a unique individual. To this end, Ginny (2012) observed that personal attributes such as the individual disposition and cultural background and prior knowledge influence the students' learning. For this reason, Gilakjani et al. (2013) suggest that the lecturer needs to take all these student variables into consideration and help students to construct new knowledge out of what they have learned into the context of their lived experiences and lives. 
In advocating for social constructivist learning, Vygotsky (1978, 1986, 1987 and 1997) is clear about the role of the significant knowledgeable persons in the teaching and learning process and the creation of knowledge, meaning and understanding. The pedagogical implication by Vygotsky (1978; 1986; 1987 and 1997) with regard to the principal role of the lecturer in a constructivist learning environment is that of scaffolding, a learning mediator and facilitator, over and above being a source of knowledge and providing support for learning. In their synopsis of Vygotsky's (1978; 1986; 1987 and 1997) views on social constructivist teaching and learning, Yadav (2016), Ginny (2012), Killen (2016), Jensen and Frederick (2016), Van Wyk (2016), Liu and He, (2014), and Ko and Chung (2014) affirm the above roles of the lecturer in a social constructivist learning environment.

An emphatic view of the above is provided by Yadav (2016), Vakalisa (2016), Gawe, Jacobs and Vakalisa (2016) and Van Wyk (2016) who all agree that the role of the lecturer in the learning environment needs to change from the all-time traditional role of prescription to the one of a learning mediator and facilitator. In the collective perspectives of Ginny (2012), Yadav (2016) and Gilakjani et al. (2013), the primary role of the lecturer in a social constructivist learning environment is to adapt to the students' needs and provide them with the freedom to construct knowledge and understanding for themselves. In this constructivist learning environment, Yadav (2016) subscribes to the earlier views of Gilakjani et al. (2013) that every student is regarded as a unique individual. Personal variables such as the individual disposition, cultural background and prior knowledge are believed by Yadav (2016) and Jensen and Frederick (2016) to have a material effect on students' learning.

The theoretical verdicts emerging from literature on the role of the lecturer in social constructivist literature suggest that lecturer quality is one of the most central and significant factors that determine the students' learning experiences and academic performance (Killen, 2016; Van Wyk, 2016; Ginny, 2012 and Vakalisa, 2016). To this end, Gilakjani et al. (2013) contend that the lecturer is even more important when considering the assumptions of social constructivism as a curriculum implementation approach. Ginny (2012) shares similar sentiments and further argues that the success of students is dependent on the lecturer's knowledge, pedagogical competencies, actions and beliefs (Van Wyk, 2016).

Recent proponents of social constructivist learning such as Van Wyk (2016), Mapuya (2018), Yadav (2016), Vakalisa (2016), Gawe, Jacobs and Vakalisa (2016), Taole and Van Wyk (2015) support the earlier views of Ginny (2012) on the factors which should guide the lecturer in social constructivist learning. Ginny (2012) suggests that when helping students to learn, the lecturer needs to pay attention to two important factors, namely the zone of proximal development and the social and cultural context of learning. Accordingly, Ginny (2012) and Yadav (2016) caution that the lecturer should consider the students' zone of proximal development and then provide students with the necessary assistance they require to construct new knowledge, understanding and meaning.

The second factor is premised on the critical stance adopted by Van Wyk (2016) and Jensen and Frederick (2016) about the social and cultural context of learning 
being a significant variable in social constructivist learning. In light of this theoretical perspective of social constructivist learning, Ginny (2012) emphasises that the lecturer should then foster, facilitate and enhance peer interaction, collaboration and cooperation among students. Contemplating on the critical role of the lecturer in the social constructivist learning environment, Yadav (2016) supports the earlier sentiments of Ginny (2012) that even though much learning is self-directed and regulated, the lecturer needs to ensure that students have access to adequately challenging material to learn and develop academically. However, Ginny (2012) warns that this learning material must not be so challenging to students that they are discouraged from their self-regulated learning. This corroborates Vygotsky's (1978, 1986, 1987 and 1997) pedagogical views on the role of the significant knowledgeable persons in social constructivist learning.

In addition, Killen (2016), Liu and He (2014) and Ko and Chung (2014) suggest that the lecturer ought to be flexible and adapt to the individual interests and learning needs of students. To this effect, Ginny (2012) believes that ensuring that the learning environment is supportive and positive is an important success factor of social constructivist teaching and learning. As argued by Yadav (2016), this gives students emotional security and confidence to challenge themselves cognitively and the courage to make mistakes, knowing that they will be corrected. Alluding to these perceptions, Ginny (2012) cautions that the lecturer needs to assure students that they are on the right track, that mistakes can be corrected and that their ideas are powerful and valuable in the learning process.

In performing the role of a learning mediator, a facilitator and scaffolder, Gilakjani et al. (2013) suggest that the lecturer ought to correct or confirm the knowledge constructed by students. In this way, Killen (2016) observed that the lecturer stimulates and enhances powerful and effective construction of knowledge, meaning and understanding. Van Wyk (2016) proposes that the constructivist lecturer is responsible for guiding and prompting students to recall experiences that can improve, develop and strengthen their prior learning. Most importantly, Yadav (2016) concurs with Taole and Van Wyk (2015) that the lecturer should give students the opportunity to choose learning activities, ask them to explain question answers and prompt them to be actively involved.

On the other hand, Gilakjani et al. (2013) and Ginny (2012) speak in one voice that the role of students in a social constructivist learning is primarily to engage and interact with each other, the lecturer, the educational materials at their disposal and the world around them. Jensen and Frederick (2016) and Ginny (2012) concur that students are able to construct knowledge, meaning and understanding through active engagement, observing and analysing the interaction of ideas and creating a cognitive framework to make sense and meaning. Ginny (2012) in particular suggests that students are usually at liberty to follow their own interests, provided they are challenging themselves to form new ideas in this process. It is the researcher's view that this is where the role of the lecturer as a learning mediator and facilitator in social constructivist learning is crucial.

In emphasising the role of students and the structuring of learning in a social constructivist learning environment, Killen (2016) and Van Wyk (2016) endorse 
the earlier perspectives of Ginny (2012) that students are not in competition with each other. Instead, students are encouraged to work collaboratively and cooperatively, sharing and exchanging ideas, knowledge and various perspectives about the subject matter. In the shared views of Mapuya (2018), Yadav (2016) and Taole and Van Wyk (2015), the above argument is consistent with what Vygotsky $(1978,1986,1987$ and 1997) referred to as the socialisation of the teaching and learning process as advanced by the social constructivist school of thought. Furthermore, Gilakjani et al. (2013) agree with Ginny (2012) that in cases where students have adequate knowledge and understanding of the content currently being dealt with, students can take up the role of the lecturer and assist their classmates. In this way, Ginny (2012) argues that such students also reinforce their own knowledge and understanding.

From the various literature perspectives presented above, it can be concluded that the construction of knowledge, understanding and meaning in a constructivist learning environment depends on the active involvement and participation of students who will be responsible for their own learning. The role of the lecturer is therefore to create and enhance an effective learning environment in which selfdirected and self-regulated learning can thrive.

\section{Implications of Learning Experiences on Curriculum Implementation}

The researcher subscribes to the sentiments of Davids and Waghid (2020) about student-centred curriculum implementation approaches. Davids and Waghid (2020) caution that the paradigm shift towards student-centred learning has some material implications for teaching and those directly involved in curriculum implementation. Lecturers are an indispensable part of curriculum implementation and cannot be detached from the learning experiences of students. In justification of this claim, Davids and Waghid (2020) indicate that lecturers do not only bring more than subject knowledge to the learning environment, but they also ensure that students achieve academic success.

Orchard, Heilbronn and Winstanley (2016) provide a more compelling and convincing analysis of why lecturers are regarded as crucial stakeholders in curriculum implementation and the learning environment as an interconnected educational and social system. Accordingly, Orchard et al. (2016) argue that lecturers influence, inspire, motivate and challenge students to explore, think deeper and step out of their comfort zone. It is the researchers' view that this is only realisable when curriculum implementation approaches do not only resonate well with the students, but are also compatible with their learning needs, thereby making them develop a deep sense of inclusion and recognition in the learning environment.

Notwithstanding the above verdicts, a study conducted by Davids and Waghid (2020) revealed that lecturers experience challenges in ensuring that students develop a sense of inclusion and recognition in the educational setup. This was attributed to the lecturers' unwillingness and incapacity to reach out to students with their diverse backgrounds, perceptions and perspectives. In this study, lecturers admitted that dealing with diverse students was a serious challenge. As 
a result, these lecturers made no attempt to know and understand all the students in the learning environment in terms of their learning needs.

Against these findings, Davids and Waghid (2020) lament that policy reform measures to transform the higher education landscape have significantly ignored who lecturers are and the dynamics which they bring to the learning environment. Davids and Waghid (2020) contend that a host of those directly involved in curriculum implementation are either not well equipped or lack the willingness and desire to implement the types of teaching practices towards student-centred learning environments. Davids and Waghid (2020) further point out that lecturers are not ready to advance participative and student- centred learning to support education and pedagogical reform in higher education.

As in the case of inclusive education, a student-centred learning environment means that all the students are accommodated in the educational setup. It further implies that all students are able to experience active involvement in teaching and learning activities because their interests, abilities, backgrounds and insights are not only valued but also taken into consideration. As cautioned by Killen (2016), a student-centred learning environment ought to acknowledge the diversity of students and encourage the participation of all students whose social and cultural backgrounds are represented.

Curriculum implementation is generally a rational and objective practice which varies from one lecturer to the other. Further to the above, Davids and Waghid (2020) subscribe to the earlier views of Orchard et al. (2016) who suggest that curriculum implementation is always shaped and affected by the various socialcultural contexts. These social-cultural contexts are also subject to constant continuous change. In the collective views of Davids and Waghid (2020) and Orchard et al. (2016), students are an essential educational resource in the learning environment. In this regard, Orchard et al. (2016) in particular argue that the identities, perspectives and perceptions of students can be exploited to enhance curriculum implementation and their learning experiences. Premised on the prognosis of Davids and Waghid (2020), this follows that curriculum implementation is not a one-dimensional process in which lecturers talk and give instructions while students are expected to listen and absorb subject content.

In contextualising the above scholarly views, it is the researchers' contention that predominantly lecturer-centred curriculum implementation approaches such as direct instruction have increasingly become obsolete in a $21^{\text {st }}$ century learning environment which is student driven. It is for this reason that Davids and Waghid (2020) argue that curriculum implementation demands contextual cognisance as demonstrated and represented by the students in the learning environment. In corroboration of this school of thought, Orchard et al. (2016) caution that curriculum implementation can neither dismiss nor neglect the importance of linking pedagogy, teaching and learning activities with issues of student diversity, their lived experiences and social justice education. 


\section{Methodology}

The study adopted a phenomenological research design which was underpinned by a qualitative research approach in generating qualitative data to answer the research questions. The research design and research approach were found to be highly compatible with the phenomena under investigation and the research questions raised. To obtain an accurate view of the constructivist learning experiences of first-year accounting student teachers, it was necessary to provide the students with an opportunity to reflect on their previous learning experiences consciously and thoughtfully. To this effect, a phenomenological research design was deemed the most suitable to generate qualitative data on the constructivist learning experiences of the study participants. The population of the study was all the first-year B.Ed. accounting student teachers.

Emphasising personal objective views on individual previous learning experiences, focus group interviews were used to enable students to share their learning experiences. A set of eight questions developed from relevant literature was used to guide these focus group discussions. Forty-eight students were randomly selected using a class list and they were then grouped into eight groups of six students for the focus group interviews. The groups for the focus group interviews were identified alphabetically from A to H. Similarly, each student in the focus group interviews was assigned a unique code with the alphabet letter of the group and the student's numerical position in the group. For instance, the first student in focus group interview A was named Student A1, while the group for the interview was named FGI GA (meaning Focus Group Interview Group A).

As one of the underlying precepts of focus group interviews and qualitative research, follow-up and probing questions were used to solicit further refined personal views from the responses. In a phenomenological qualitative research, reality is both objective and mutually negotiated; therefore, the students were allowed to deliberate on their individual constructivist learning experiences in relation to a question. Content analysis and qualitative coding were used to analyse data, paying particular attention to the main ideas emanating from the respondents' responses. As discussed below, these responses were then grouped into themes and sub-themes, based on the meaning they conveyed about the constructivist learning experiences of the first-year accounting student teachers.

As a measure to ensure the validity and truthfulness of data and the ultimate findings of the study, the techniques of validation and member checking were used. Thus to ensure that the views and intended meanings of the participants have been accurately captured and interpreted, the study made use of member checking. This follows that the main and sub-themes which emerged from the focus group interviews were communicated to the participants for verification purposes and confirmation of the truthfulness thereof. Through this process, the researcher ensured that the participants concurred with the findings. In this way, the participants were given an opportunity to endorse the findings as valid, truthful and as an accurate representation of their views and perceptions on their constructivist learning experiences. 


\section{Research Findings}

After a rigorous thematic analysis of the qualitative sentiments of students, the following main themes emerged and were clearly distinguishable.

\section{- The Student Teachers' Constructivist Learning Experiences}

Despite the availability of an avalanche of scientific evidence to support and advocate for constructivist learning environments (Killen, 2016; Van Wyk, 2016; Ginny, 2012; Mapuya, 2018; Yadav, 2016; Taole and Van Wyk, 2015; Vygotsky, 1978; 1986; 1987 and 1997; Gilakjani et al., 2013), the findings of this study point to serious deficiencies in its application in accounting education. On the basis of the phenomenological voices and verdicts of students, this study established that the principles of social constructivism are not implemented in the accounting class. All students were unanimous that the learning environment is predominantly lecturer-centred and agonisingly abstract.

Evidence in corroboration of the above findings is found in the phenomenological voice of student $\mathbf{C 1}$ in FGI GC who bemoaned:

"Dr Mapuya, every Accounting class is like a church sermon. Mnr [Mr] only does the talking while we listen attentively. Like congregants in church, we can't even talk and ask questions during the lesson presentation. He takes asking questions as unnecessary interruptions which must be avoided at all costs"

With reference to the above views of student C1, student D3 in FGI GD confirmed:

"A successful lesson presentation according to his criteria is one in which no student interrupted the lesson to ask a question. Ntate [Mr] enjoys all the control over lesson proceedings and simply expects us to adhere to instructions"

In another separate focus group interview session, student A5 in FGI GA had this to say:

"As students, we feel reduced to learning robots which are just supposedly programmed to absorb information in the accounting class and follow instructions without fail. Our individuality, learning needs and learning preferences are thrown out of the window in that class sir"

To amplify the degree of lecturer-centeredness in the learning environment and the absence of student involvement and participation in the lesson, student $\mathbf{B} 3$ in FGI GB remarked:

"I wish the accounting lecturer can involve us more in the lesson through class discussions, group discussions or thought provoking questions"

The findings on the role of the lecturer in the constructivist learning environment are presented below:

- The Role of the Lecturer in a Constructivist Learning Environment While there is very little comparative empirical research on social constructivism in accounting education to interrogate this finding, this theme was found to be consistent with the one above on the students' learning experiences in the accounting learning environment. All the students share similar views on the 
lecturer being in total control of the lesson, without any interactions or input from students. The lecturer dictates the pace of the lesson and selects activities for students from the textbook.

To vindicate the above findings, student D1 in FGI GD lamented:

"Personally, nna (I), I think that our lecturer thinks that we are clueless about everything that he teaches. So he finds no point in involving us. He believes we cannot contribute positively towards the success of the lesson"

In agreement with the above perspective of the role of the lecturer in the learning environment, student E6 in FGI GE had this to say:

"Our duty is to listen and absorb information and not to ask questions.

We can only ask questions to our classmates in our study groups or group discussions."

In FGI GD, student D2 commented:

"I am sorry to say this, but the lessons are presented in a dictatorial manner. How can asking questions about something you don't understand be regarded as a disruption of the lesson?"

Shedding more light on the idea of the lecturer playing a predominantly direct instruction role during lesson presentation, student H4 in FGI GH remarked:

"Reading out to us from the textbook and telling us which activities to do from the textbook is all we get exposed to in class"

Below are the findings on the implications of the students' constructivist learning experiences on curriculum implementation:

- Implications of the Students' Constructivist Learning Experiences on Curriculum Implementation

The phenomenological voices of the students suggest that curriculum implementation approaches have a substantial effect on their learning experiences. The students are unanimous that the experiences of alienation, marginalisation, disempowerment, worthlessness and boredom are fundamentally a result of the manner in which the lesson and learning activities are structured.

In justification of the above verdict, student F1 in FGI GF shared the following views:

"Reading to us, denying us the chance to ask questions and giving us orders in class makes us feel useless sir. It's like we are all empty vessels. I see no reason in attending those reading sessions."

Student B6 in FGI GB also concurred with F1 in FGI GF by saying:

"Our views about the lesson do not matter at all. We are just students. It ends there."

Similar views were also conveyed by student E3 in FHI GE who claimed:

"These lessons are boring because we are not involved or regarded as an important role player in the lesson." 
Perhaps a more vivid picture of the influence of curriculum implementation approaches on the students' learning experiences was portrayed by student $\mathbf{C 6}$ in FGI GC whose contribution was:

"We sleep in class. We do not attend classes. No desire to be there in any way. All because of one-way communication, no interactions, no questions, no discussions, no effort to get our views on the subject matter, only a one-man show."

The findings above are now discussed in light of other perspectives from the literature. Thereafter, recommendations are made.

\section{Discussion, Conclusions and Recommendations}

The phenomenological verdicts of students present compelling evidence to conclude that they are not exposed to any social constructivist teaching in the accounting class. However, this is not the only study to deliver such a verdict. Investigations by Yadav (2016), Liu and He, (2014), Mapuya (2018) and Ko and Chung (2014) also delivered a similar diagnosis where the learning environment was highly structured and predominantly lecturer-centred. The manner in which teaching and learning activities are structured in the learning environment for accounting bears no resemblance to the principles of social constructivism. However, what this study and the previous ones fail to indicate are the underlying causes of these deficiencies in the application and implementation of social constructivist pedagogical assumptions in the learning environment. Thus, there is a need for further investigation into the lack of application of constructivist principles as a function of the lecturers' reluctance or lack of knowledge and skills in their application.

Contrary to the views emanating from literature perspectives on the role of the lecturer in a social constructivist learning environment (Ginny, 2012; Yadav, 2016; Gilakjani et al, 2013; Killen, 2016 and Van Wyk, 2016), this study has produced convincing evidence to conclude that the role of the lecturer in the accounting class is predominantly to pass information and knowledge to students in one-way communication. Furthermore, the lecturer has emerged as an absolute source of knowledge who is firmly in full control of the leaching and learning proceedings. While this finding is inconsistent with literature verdicts produced by Yadav (2016) and Ginny (2012), it endorses the earlier finding about the lack of social constructivist pedagogical principles in the learning environment. Therefore, it confirms the cautions of Vygotsky (1978, 1986, 1987 and 1997), Killen (2016), Horsthemke, Siyakwazi, Walton and Wolhuter (2013), Jacobs (2016), Daniel and Bimbola (2010) and Evans et al. (2010) about what lecturers should avoid in order to create and enhance an ideal social constructivist learning environment.

With regard to the implications of the students' learning experiences on curriculum implementation, the findings of this study concur with the sentiments of Vygotsky (1978., 1986, 1987 and 1997), Jensen and Frederick (2016), Mapuya (2018), Van Wyk (2016), Vakalisa (2016), Gawe et al. (2016), Ginny (2012) and Gilakjani et al. (2013) which emphasise the significant influence of curriculum implementation approaches on the students' learning experiences. Accordingly, this study found that the approaches used to implement the accounting 
curriculum have a direct impact on the learning experiences of students. Predominantly lecturer-centred curriculum implementation approaches have been found to be negatively associated with positive learning experiences for students. On the other hand, curriculum implementation approaches which are collaborative and participative in nature and which prioritise active student involvement and participation have revealed a positive influence on the students' learning experiences. It therefore follows that curriculum implementation approaches should not only be informed by the learning preferences and needs of students but also by their learning experiences, as echoed in their reflective phenomenological voices.

In addition, the study also found that there is a serious need to adopt curriculum implementation approaches that assist students to develop some degree of resonance with the learning environment. This finding supports the sentiments of Davids and Waghid (2020) that owing to lack of radical transformation in the higher education landscape, most students feel alienated from the learning environment and the institution itself. To this effect, curriculum implementation approaches need to promote and encourage student autonomy, self-regulation, real life-based learning, collaborative group work, learning beyond the learning environment and a less structured learning environment in which student creativity can thrive.

While the evidence generated by this study on social constructivist learning is not absolute or conclusive, it does provide a scientific and empirical basis to argue for a radical paradigm shift in the curriculum implementation approaches used in higher education. On the premises of the findings of this study, there is a need to migrate from a predominantly lecturer-centred to a more student-centred participative, consultative and collaborative learning environment where students have collective ownership of academic failure or success. It is further recommended that the learning environment should be revolutionised and undergo some radical changes in terms of lecturer support.

Lecturers need to adopt a radical shift and move away from lecturer-centred approaches to participative and interactive student-centred approaches. These recommendations are also supported by Zhang, Olfma and Firpo (2010) and Davids and Waghid (2020) who believe that for students to feel included and acknowledged in the learning environment, it is essential to ensure that the dynamic and diverse identities of students, their backgrounds, lives, and forms of knowledge are resembled and reflected in the teaching and learning process and activities. This recommendation is also consistent with the pronouncements of the Department of Higher Education and Training (2015) in terms of the minimum requirements of teacher education qualifications in a South African context.

Lecturers need to realise that students are not cognitive machines or devices which they can switch on and off at their convenience without any due consideration of their learning needs. A constructivist learning environment demands the active involvement and participation of students in the teaching and learning process. As part of transforming the learning environment, it is important to empower lecturers with the necessary competencies and skills 
required for constructivist pedagogies. To this effect, institutions of higher learning should invest in lecturer training programmes and workshops on constructivist teaching. At the centre of these lecturer-empowerment initiatives should be training on their role as learning mediators in a constructivist learning environment. This study concurs with the recommendations of Khechane, Makara and Rambuda (2020) and Killen (2016) about obtaining evaluative feedback and enhancing a more participatory and interactive learning environment in which students are given feedback about their learning progress. This study therefore recommends that in order to always be up-to-date with the learning needs, learning experiences and expectations of students, lecturers need to obtain regular feedback from students to this effect.

The findings of this study, together with the scholarly views from literature perspectives, provide a strong and powerful basis to advocate for social constructivism in accounting education. Conclusively, social constructivism is premised on the active engagement and participation of the accounting students and the accounting lecturer in an accounting learning environment. This study contends that social constructivist teaching and learning provides students with the much needed practical learning, negotiated meaning, problem-solving, evaluative, and analytical skills and understanding in accounting education.

\section{References}

Akalu, G. A. (2017). Higher education "massification" and challenges to the professoriate: Do academics' conceptions of quality matter? Quality in Higher Education, 2(3), 260-276.

Bautista, R. G. (2012). The effects of personalized instruction on the academic achievement of students in Physics. International Journal of Arts \& Sciences, 5(5), 573-583.

Bosman, A. (2015). The relationship between student academic achievement and student learning styles in a multicultural senior school [PhD Thesis]. University of South Africa. http://uir.unisa.ac.za/bitstream/handle/10500/20187/thesis_bosman_a.pdf? sequence $=1$

Daniel, I. O., \& Bimbola, O. (2010). Effects of constructivist- based teaching strategy in integrated science at junior secondary school level. Academic Journal. Educational Research and Reviews, 5(7), 344- 353.

Davids, N., \& Waghid, Y. (2020). Tracking five years of teacher education enrolment at a South African university: Implications for teacher education. South African Journal of Higher Education, 34(2), 1-16. doi:10.20853/34-2-4044

Du Toit, G. (2018). The student teacher and the teaching context. In : E. R. du Toit, L. P. Louw \& L. Jacobs (Eds.). Help. I am a student teacher. Skills development for teaching practice. Van Schaik Publishers.

Fardon, M. (2013). Relationships between students' learning style preference and exam achievement in differing forms of assessment during an advanced apprenticeship at a vocational Further Education College. Institute of Learning, Department of Education, University of Oxford.

Fayombo, G. A. (2014). Enhancing learning outcomes in psychology through active learning strategies in classroom and online learning environments. International Journal of Learning and Development, 4(4), 114-130. doi:10.5296/ijld. v4i4.6703

Fayombo. G. (2015). Learning styles, teaching strategies and academic achievement among some psychology undergraduates in barbados. Caribbean Educational Research Journal, 3(2), 46-61. 
Gawe, N., Jacobs, M., \& Vakalisa, N. C. G. (2016). Learner-centred methods. In: M. Jacobs, N. C. G. Vakalisa \& N. Gawe (Eds.). Teaching- Learning Dynamics (5 $5^{\text {th }}$ edition). Pearson.

Gilakjani, A. P., Leong, L. M., \& Ismail, H. N. (2013). Teachers' Use of technology and constructivism. I. J. Modern Education and Computer Science, 4, 49-63.

Ginny, P. (2012, March 14). Constructivism: Roles of teacher and learner. Constructivist and Existentialist

Education. https://constructivismandexistentialism.wordpress.com/2012/03/14/construct ivism-roles-of-teacher-and-learner

Hodgson, P., Lam, P., \& Chow, C. (2010). Assessment experience of first-year university students: Dealing with the unfamiliar. Bristol: CETL.

Horsthemke, K., Siyakwazi, P., Walton, E., \& Wolhuter, C. (2013). Education studies. History, Sociology, Philosophy. Oxford University Press.

Jacobs, M. (2016). Aims and objectives. In: M. Jacobs, N. C. G. Vakalisa \& N. Gawe (Eds.), Teaching- Learning Dynamics (5 $5^{\text {th }}$ edition). Pearson.

Jensen, J. W., \& Frederick, H. (2016). Using constructivism as an alternative to teachercentred instruction. In: K. Alexander (Ed.), Teaching family and consumer sciences in the 21 century. Lubbock, TX: Texas Tech University.

Khechane, N. C., Makara. M. C. \& Rambuda, A. M. (2020). Primary mathematics teachers' assessment practices in the context of the integrated primary curriculum in Lesotho. African Journal of Research in Mathematics, Science and Technology Education, 24(1), 41-52.

Killen, R. (2016). Teaching strategies for quality teaching and learning. Claremont: Juta.

Ko, W. H., \& Chung, F. M. (2014). Teaching quality, learning satisfaction, and academic performance among hospitality students in Taiwan. World Journal of Education, $4(5), 63-70$.

Liu, J. F., \& He, Q. S. (2014). The match of teaching and learning styles in SLA. Creative Education, 5, 728-733.

Lombard, K., \& Themane, M. (2015). Contextualising teaching practice as a component of teacher education. In: M. J. Taole (Ed.), Teaching practice, perspectives and frameworks. Van Schaik.

Makola, S. (2016). Find meaning, stop wondering: Assisting youth to find meaning and achieve success in their studies. Unisa Press.

Mapuya, M. (2018). First-year student teacher's perceptions of their constructivist learning environments in accounting 1 and implications for teacher educators [Master's dissertation]. Faculty of Humanities, Central University of Technology, Free State.

Mbude, P. (2018). 85\% of South African learners aspire to go to university - where will they end up? News24. https://www.w24.co.za/SelfCare/Wellness/Mind/85-of-southafrican-learners-aspire-to-go-onto-university-where-will-they-end-up-20181123

Millet, H. K. (2015). The year of challenge: Challenges faced by first-year students based on individual identities [Bachelor Thesis]. Faculty of the Undergraduate College of Arts and Letters, Department of Sociology and Anthropology, James Madison University. https://commons.lib.jmu.edu/honors201019/102

Nel, N., Nel, M., \& Hugo, A. (2012). Learner support in a diverse classroom: A guide for foundation, intermediate and senior phase teachers of language and mathematics. Van Schaik.

Nie, Y., \& Lau, S. (2010). Differential relations of constructivist and didactic instruction to students' cognition, motivation, and achievement. Learning and Instruction, 20(5), 411-423.

Orchard, J., Heilbronn, R., \& Winstanley, C. (2016). Philosophy for teachers (P4T): Developing new teachers' applied ethical-decision making. Ethics and Education, 11(1), 42-54. 
Ormrod, J. E. (2014). Educational psychology. Developing learners. Pearson International Education Edition.

Peach-Squibb, J. (2014). Constructivist learning. Promoting constructivist learning using ICTs. EDUTECH

WIKI.

http:/ / edutechwiki.unige.ch/mediawiki/index.php?oldid=48654

Pieterse, E. V. H. (2015). Life skills: My journey, my destination. Van Schaik.

Pollard, A. (2014). Reflective teaching in schools. Bloomsbury.

Radovan, M., \& Makovec, D. (2015). Relationship between students' motivation and perceptions of the learning environment. CEPS Journal, 5(2), 115-138.

Republic of South Africa. (2015). National Qualifications Framework Act, 2008 (Act No. 67 Of 2008): Revised Policy On The Minimum Requirements For Teacher Education Qualifications Training (Government Gazette No. 38487). Department of Higher Education and. https://www.dhet.gov.za/Teacher\%20Education/National\%20Qualifications\% 20Framework\%20Act\%2067_2008\%20Revised \%20Policy\%20for\%20Teacher\%20E ducation\%20Quilifications.pdf

Seroto, J. (2015). Diversity education in the classroom. In: M. J. Taole (Ed.), Teaching practice, perspectives and frameworks. Van Schaik.

Taole, M. J., \& Van Wyk, M. (2015). Reflective practice in teacher education. In: M. J. Taole (Ed.), Teaching practice, perspectives and frameworks. Van Schaik.

Taole, M. J. (2015). Reflective teaching. In: M. J. Taole (Ed.), Teaching practice, perspectives and frameworks. Van Schaik.

Tulbure, C. (2012). Learning styles, teaching strategies and academic achievement in higher education: A cross-sectional investigation. Procedia - Social and Behavioral Sciences, 33, 398-402. doi:10.1016/j.sbspro.2012.01.151

Vakalisa, N. C. G. (2016). Participative teaching. In: M. Jacobs, N. C. G. Vakalisa \& N. Gawe (Eds.), Teaching- learning dynamics ( $5^{\text {th }}$ edition). Pearson.

Van Wyk, M. (2016). Approaches to teaching EMS: The learner-centred approach. In: M. van Wyk \& K. Dos Reis (Eds). Teaching economic and management sciences in the senior phase. Oxford University Press.

Visser, S., \& Vreken, N. (2013). Teaching styles versus learning styles in the accounting sciences in the United Kingdom and South Africa. A comparative analysis. Meditari: Research Journal of the School of Accounting Sciences, 14(2), 97-112. doi:10.1108/10222529200600015

Vygotsky, L. S. (1997). Educational psychology. St Lucie Press.

Vygotsky. L. S. (1978). Mind in society: The development of higher psychological processes. Harvard University Press.

Vygotsky. L. S. (1986). Thought and language. The MIT Press.

Vygotsky. L. S. (1987). The collected works of L. S. Vygotsky. In: R. W. Rieber \& A. S. Carton (Eds.), Problems of General Psychology, Including the Volume Thinking and Speech (Vol. 3). Plenum Press.

Wangeri, T., Kimani. E., \& Mutweleli, S. M. (2012). Transitional challenges facing university first year students in Kenyan public universities: A case of Kenyatta University. Interdisciplinary Review of Economics and Management, 2(1), 41-50.

Yadav, R. (2016). Role of constructivism in learning. International Journal of Educational Studies, 3(3), 93-97.

Zhang, X., Olfma, L., \& Firpo, D. (2010). Supporting social constructivist learning through the KEEP SLS ePortfolio System. International Journal on E-Learning, 9(3), 411-426. 